\title{
NATO's New Energy Security Role in Azerbaijan: Balancing the Interest between West and Russia
}

\author{
NATO’nun Azerbeycan Enerji Güvenliğindeki Yeni Rolï: \\ Azerbeycan'ın Batı ve Rusya Arasındaki Çıkar Dengesi
}

\author{
Hasan KORKUT* \\ Hamza PRELJEVÍC ${ }^{\star *}$
}

\begin{abstract}
Considering the contemporary developments in the international relations, the Azerbaijan's relations with North Atlantic Treaty Organization (NATO) are of great significance. Due to the rich oil and gas reserves and Azerbaijan's geostrategic importance as an energy crossroad between Europe and Asia, the country has always been attractive for many actors after the collapse of the Soviet Union. Not only the neighboring countries Turkey, Iran and Central Asian countries, but also the United States, European Union (EU) and China. Therefore, Azerbaijan tries to gain the maximum from the geostrategic position, but at the same time the country must play carefully in the foreign policy creation. Azerbaijan is committed to the cooperation with the Western countries, particularly with NATO alliance and the EU, to downturn the Russian influence. Stronger cooperation with NATO could also mean stronger cooperation with the EU member states. On the other hand, the energy security is becoming an increasingly important issue in the domain of energy. One of the key tasks of the national security of Azerbaijan is ensuring the security of energy corridors and the transportation of the energy resources. The critical energy infrastructure in Azerbaijan is not only important to the country itself, but also to EU and NATO. How does access to and transit of energy sources from the Caspian Region influence NATO-Azerbaijani relationship? The energy supply map is much internationalized, and the protection of critical energy infrastructure goes beyond the national level. This requires from Azerbaijan to seek for regional cooperation and stable regional security, which could be assisted by NATO. The Alliance supported an active role for NATO in ensuring the security of energy supplies for the allies, but also they supported the assistance in the energy security for the partner states. Most EU member states are also members of NATO, and energy security may emerge as an issue handled in a joint initiative by these two organizations. This paper discusses the Azerbaijani critical energy infrastructure, and NATO's possible role in the protection of the energy infrastructure. Also, the paper discussed NATO's reasons for being involved in the energy security, and how NATO's energy security evolved from Riga Summit Declaration in 2006 to Warsaw Summit Communiqué in 2016. More importantly, this paper will answer to what extent the changes in NATO's security policy affects Azerbaijan.
\end{abstract}

Keywords: Azerbaijan, NATO, European Union, Russia, Critical Energy Infrastructure, Energy Security

* PhD, International University of Sarajevo, hkorkut@ius.edu.ba.

** PhD Candidate, International University of Sarajevo, hpreljevic@ius.edu.ba. 


\section{Öz}

Günümüz uluslararası ilişkileri dikkate alındığında Azerbaycan-NATO ilişkileri büyük bir öneme sahiptir. Sovyet Rusya `nın çökmesinden sonra Azerbaycan zengin gaz ve petrol yataklarına sahip olması ve Asya ve Avrupa arasinda enerji koridoru olmaktan kaynaklanan geostartejik konumu dolayısıyla bir çok aktörün ilgi duyduğu bir ülke konumundadır. Bu aktörler arasında Azerbaycan ’a komşu olan Türkiye, İran ve Orta Asya ülkelerinin yanı sıra, aynı zamanda Amerika, Avrupa Birliği ve Çin de vardır. Bu nedenle Azerbaycan bir taraftan geostratejik konumundan en üst düzeyde kazanç elde etmeye gayret gösterirken, aynı zamanda da dış politika faaliyetlerinde çok dikkatli olmak durumundadır. Azerbaycan Rusya `nın etkisini azaltmak için Batılı ülkelerle, özellikle NATO ittifakı ve $A B$ ile işbirliğine büyük önem vermektedir. NATO ile güçlü ilişkiler $A B$ üyesi ülkelerle kurulmuş güçlü ilişkiler anlamına gelmektedir. Diğer yandan enerji güvenliği, enerji alanında giderek daha önemli bir konu olmaya başlıyor. Azerbaycan ulusal güvenliğinin önemli görevlerinden biri enerji koridorlarının güvenliğini ve enerji kaynaklarının taşınmasını sağlamaktır. Azerbaycan'daki kritik enerji altyapısı ülkenin kendisi için olduğu kadar Avrupa Birliği ve NATO için de çok önemlidir. Hazar bölgesinin enerji kaynaklarına giden ulaşım ağları ve kaynakların taşınma süreçleri Azerbaycan -NATO ilişkilerini nasıl etkilediği önemli bir sorudur. Enerji arz haritası uluslararasılaşmıştır ve kritik enerji altyapısının korunması ulusal seviyenin ötesine geçmektedir. Bu, Azerbaycan'a NATO’nun destekleyebileceği istikrarlı bölgesel güvenlik ve bölgesel işbirliği arayışını gerekli kılmıştır. İttifak, müttefiklerinin enerji kaynaklarının güvenliğinin sağlanmasında NATO için etkin bir rol oynamıştır. Ancak aynı zamanda ortak ülkeler için enerji güvenliğindeki yardımı da desteklemişlerdir. Çoğu AB üyesi ülkeler aynı zamanda NATO’nun da üyesidir. Enerji güvenliği, bu iki organizasyon tarafından ortak bir girişimde ele alınan bir mesele olarak ortaya çıkabilir. Bu çalışma Azerbaycan`ın kritik enerji alt yapısını ve NATO nun sözkonusu enerji altyapısının güvenliğinin sağlanmasındaki olası rolünü tartışmaktadır. Çalışma ayrıca NATO`nun neden enerji güvenliğiyle ilginlediğini ve 2006 Riga Zirvesi`nden 2016 Warşova Zirvesi 'ne NATO `nun enerji güvenliği konusunda geçirdiği evrilmeyi tartışmaktadır. Daha da önemlisi, bu çalışma NATO’nun güvenlik politikasındaki değişikliklerin Azerbaycan’ı ne ölçüde etkilediğini cevaplayacaktır.

Anahtar Kelimeler: Azarbeycan, NATO, AB, Rusya, Kritik Enerji Altyapıları, Energi Güvenliği

\section{Introduction}

Azerbaijan declared its independence on 18 October 1991. As a newly independent state after the collapse of the Soviet Union, Azerbaijan established good relations with the Western powers - the United States and European Union, which were particularly interested in the Azeri gas and oil reserves (Ismayilov and Zasztowt, 2015). This marked “Great Game” over the Azerbaijan's natural resources, which has led to an extraordinary amount of foreign investment flowing into the oil and gas sectors.

During the early days of the independence, Azerbaijan presented its commitment to the integration in European and Euro-Atlantic communities. The origin of Azerbaijan-NATO relations dates back to 1992 when Azerbaijan together with several other Central and Eastern European countries, joined a newly established consultative forum - the North Atlantic Cooperation Council (NACC), which was transformed into the Euro-Atlantic Partnership Council in 1997. On 4 May 1994, the President of Azerbaijan Heydar Aliyev signed the Partnership for Peace (PfP) Framework 
Document and Azerbaijan joined the PfP Programme. Also, since 2005, Azerbaijan actively cooperates with NATO through the Individual Partnership Action Plan (IPAP) (Mammadov, 2010).

However, the Azerbaijani aspiration for the integration to Euro-Atlantic Community does not mean absolute commitment for the membership. Azerbaijan was aware of the regional framework of the South Caucasus, and 2011, Azerbaijan joined the Non-Aligned Movement (NAM). With such a decision, Azerbaijan tried to avoid a potential conflict with Russia and Iran, two countries that oppose NATO expansion in the South Caucasus (Shiriyev, 2015).

Nevertheless, the Russia-NATO tensions over the Ukraine Crisis in 2014 brought Azerbaijan closer to NATO. Azerbaijan and Ukraine are two pivotal states in the Black Sea (Caspian region), strategically located at the gateway to Eurasia. The US geostrategic philosophy defines both countries as geopolitical states of critical importance at the end of the 1990s. Moreover, Russia sees Azerbaijan as a potential target of high priority, and the dominance over this region would help seal Central Asia off from the West (Guliyev, 2014).

In light of Russian efforts to improve its position in the Azerbaijani politics, Russia empowered the bilateral relations with Armenia in 2013 which started as early as 1992, which showed that Armenian-Russian relationship is stable in the post-Soviet era. On 2 December 2013, the President of the Russian Federation Vladimir Putin paid a state visit to the Republic of Armenia. "The directions on further development of bilateral interaction, issues on trade and economic and humanitarian cooperation, perspectives of participation of Armenia in integration processes in the Eurasian region were discussed during the visit" (Ministry of Foreign Affairs of the Republic of Armenia, 2016). Additionally, security and economy are in the focus of this cooperation, but cultural and humanitarian aspects are also included (Minasyan, 2013). The Armenian-Russian cooperation in military sphere is aimed at ensuring security of the two states and stability in Transcaucasia. The Russian 102nd military base is dislocated in the territory of Armenia (Ministry of Foreign Affairs of the Republic of Armenia, 2016).

During the Nagorno-Karabakh dispute ${ }^{1}$, Russia was openly on the Armenian side, which threatened the Azerbaijan's interest. The conflict has resulted to a considerable refugee crisis and the violation of basic human rights and needs. As early as the conflict started, Armenia was intentionally occupying the internationally recognized territory of Azerbaijan under the pretext of a right of the ethnic Armenians living in Nagorno-Karabakh for national self-determination. As a result of the war, Armenians took control of Karabakh and much of the Azerbaijani territory around it (MacDougall, 2009). The Armenian-Azerbaijani is considerably complex having in mind that the external actors are also incorporated. The Russian Federation is one of them. Huge number of Russian companies and corporations operate in Armenia; therefore, Armenia could serve as a bridge between Russia and Iran. Armenia is geo-strategically important for Russia.

1 Since 1988, a conflict endured between Azerbaijan and Armenia over the disputed area of Nagorno-Karabakh. 
The Armenian-Azerbaijani conflict could be a Russian leverage for influence over Azerbaijan. Weakening the Azerbaijani position in the Nagorno-Karabakh conflict is a kind of guarantee of keeping strong Western present between Iran and Russia. However, the stronger ArmenianRussian alliance, the greater Azerbaijan's need for alternative security option was. Because of its geographical position, the only visible Azerbaijani security alternative (option) is the tightening of NATO-Azerbaijani relations. Therefore, the fundamental misinterpretation of the conflict has to keep Azerbaijan close to the Western powers in order to check-and-balance the relations in the region by having Russia on the counter side.

Today, Azerbaijan holds a geostrategic value due to its gas and oil reserves to the European Union, and is one of the real alternatives to the Russian dominance in gas market. The territorial security of Azerbaijan is crucially important both to NATO and the EU, and for this reason the cooperation between NATO and Azerbaijan has expended.

The critical energy infrastructure in Azerbaijan is not only important to the country itself, but also to EU and NATO. The energy security is becoming an increasingly important issue in the domain of energy. The concept of security of supply has different interpretations and approaches. The literature is divided between those who interpret energy security from an economic point of view and those who interpret energy security from a political and strategic view. Both of the approaches are incorporated in the energy relations between Azerbaijan and the Western countries. From an economic point of view, many questions are still unclear, but cost of energy infrastructure insecurity might be an answer to this. In case of Azerbaijan, the economic concept is associated with heavy investment of Western companies in the energy domain of Azerbaijan. From the political and strategic point of view, the main related issue is to reduce the dominance of Russia's natural resources in the European market.

Additionally, how does the transit of energy sources affect the Azerbaijani-NATO relations? The concept of energy security itself refers to the availability of sufficient energy supplies at affordable prices, thus focusing on the supply-side of the energy domain (Labandeira and Manzano, 2012). The Alliance supported an active role for NATO in ensuring the security of energy supplies for the allies, but also they supported the assistance in the energy security for the partner states. In addition, most EU member states are also members of NATO, and energy security may emerge as an issue handled in a joint initiative by these two organizations. This paper discusses the Azerbaijani critical energy infrastructure, and NATO's possible role in the protection of the energy infrastructure. Also, the paper discussed NATO's reasons for being involved in the energy security, and how NATO's energy security evolved from Riga Summit Declaration in $2006^{2}$ to Warsaw Summit Communiqué in 2016. More importantly, this paper will answer to what extent the changes in NATO's security policy affects Azerbaijan.

2 With the Riga Summit 2006, NATO recognized the need to defend its vital strategic interest - securing accessibility to natural resources and diversifying the suppliers. 


\section{Theoretical background}

The issue of energy security achieved a particular importance since the energy shock of the 1970s, when present asymmetries between the geographical distribution of resources and energy consumers has been consolidated by oil shortage in the petroleum-dependent countries (Choucric, 1977). The same applies to other natural (energy) resources. Since the 1970s, the energy security has been integrated in the international relations. The energy security per se is a broader issue-complex related to international trade, supply and pricing.

Azerbaijan is hydrocarbon rich and has a history of oil and gas production, transportation and refining stretching back to ancient times (Rzayeva, 2015). Because of its geo-strategic position and the natural resources, Azerbaijan plays an important role to NATO. In this case, we could ask the question how does access to and transit of energy sources from the Caspian Sea influence NATO-Azerbaijan relations. The safety of the energy corridors is important for NATO partners in Europe. In order to provide a comprehensive understanding regarding the geopolitics and geo-strategy in NATO-Azerbaijan relations, two different theoretical perspectives have been employed in this paper: the balance of threat theory and the rational-choice institutionalism theory.

The balance of threat theory is an opposite approach to the "balanced foreign policy" doctrine which is employed in Azerbaijani foreign policy. Although this doctrine is still in use, the Ukraine crisis in 2014 challenged the doctrine's discourse. As a result, Azerbaijan showed more openness and aspiration to NATO. The motive of NATO-Azerbaijan relations and the aim of the two actors to tighten the relations could be approached through the balance of threat theory. According to balance of threat theory, states' alliance behavior is determined by the threat they perceive from other states, or states are joining alliance to avoid dominance by other states (Walt, 1990). Many Western countries are highly concerned about the safeness of Azerbaijan because of its geostrategic importance. Azerbaijan and Ukraine are two pivotal states in the Black Sea, strategically located at the gateway to Eurasia. Russia sees Azerbaijan as a potential target of high priority, the subordination of which to Russia would help seal Central Asia off from the West (Guliyev, 2014). Similar Russian attitude can be seen through the Georgian-Russian War in 2008, and the Russian annexation of Crimea and support for separatism in Ukraine in 2014. Soon after the Russian involvement in Ukraine, NATO suspended the relations with Russia (NATO, 2016).

The future conflict in the Black Sea (Caspian region) could turn Russia towards Azerbaijan because of the geo-strategic importance, which would help Russia to seal Central Asia off from the West. In light of Russia to improve its position in the Azerbaijani politics, in 2013, Russia established bilateral relations with Armenia (Minasyan, 2013). Therefore, the ArmenianAzerbaijani conflict could be a Russian leverage for influence over Azerbaijan. On the other side, closer NATO-Azerbaijan relations would prevent such a scenario to appear.

The second theoretical perspective which could be applicable to NATO-Azerbaijan relations is the rational-choice institutionalism theory. This theory is a study of institutions, and argues that 
actors use institutions to maximize their utility. It assumes that actors establish or join institutions to maximize their benefits which are often conceptualized through strategic cooperation (Shepsle, 2008). Additionally, the existence of any institution by the rational-choice institutionalism is explained by referencing the benefits that the member states gain. The institutions emerge and survive, because they fulfill important functions for actors affected by these institutions; and actors are joining the institutions because of the overall benefits. These institutions "are the result of rational, purposive interactions among states and other international actors to solve specific problems" (Koremenos and Lipson, 2001, p. 2). NATO as a rational-purposive organization could help Azerbaijan to overcome challenges regarding the energy security.

When we look at NATO, we can determine that the organization shifted from a defense to security alliance after the demise of the Iron Curtain. The rational-choice institutionalism theory argues that the persistence of NATO during the post-Cold War era for the organizational existence can be determined through the adoption of new security assets for dealing with environments without threats (Wallander, 2000). In regards, NATO's adoption of new specific assets, such as energy security, addresses new security concerns in a collective and beneficial manner for NATO member and partner states. For instance, in 2014, at the Wales Summit, NATO adopted new forms of cooperation with the partner states, and three of them refreshed the Azerbaijani-NATO sphere of cooperation: energy and cyber security, defense sector reform, and humanitarian assistance (NATO, 2016).Therefore, strengthening the strategic relations with NATO would improve the energy security in Azerbaijan, as well as the access to the energy resources by NATO member states. The security of the Azerbaijani energy resources, as well as the accessibility to the natural resources would empower the Azerbaijani economy. From a rational-choice institutionalism approach, NATO would provide energy security to Azerbaijan; but in return Azerbaijan will need to sacrifice some old practices in the foreign policy.

The rational choice institutionalism theory suggests that the institutions are in the equilibrium of doing things. According to Kenneth A. Shepsle, "if a decisive player wants to play according to different rules - like the kid who threatens to take his bat and ball home if the rules are not adjusted to his liking - then the rules are not in equilibrium and the 'institution' is fragile" (Shepsle, 2008, p.26). In Azerbaijan's case this would mean, if Azerbaijan wants to tighten the cooperation with NATO in the security aspects, the country must modify the "balanced foreign policy" doctrine introduced by second post-independence president Heydar Aliyev. Our basic presumption, grounded in the broad tradition of rational-choice institutionalism analysis, is that Azerbaijan could use NATO to further its own goals.

\section{Three significant reasons of NATO's involvement in energy security}

NATO's interest in the energy security cannot be explicitly only explained by the threat of natural disaster or terrorist attacks, which exist since the last few decades, or by the trend of changing the market (Legendre, 2007). The energy crisis is not something that developed out of the September 
11, 2001, the terrorist attack; nor it existed in the past (e.g. oil crisis in 1973). But the energy security was more often used as a post-Cold War outcome.

NATO's dilemma regarding energy security is closely linked to its struggle to help its members in Europe to diversify their energy resources supplies, which would help seal Europe from Russian influence. Currently NATO cannot avoid discussing the energy security; the energy security becomes an essential NATO policy. The rise of energy security as a challenger to NATO and the factors that shape the energy security explain the contemporary global security framework. This clearly shows the transformation of NATO during the post-Cold War period. NATO is not deal anymore only with the outside threats to the member states, nor includes a comprehensive security aspects. Being defined as a global problem, energy security requires a global treatment and, hence, increased attention by multinational organizations like NATO (NATO Review, 2007).

There are few fundamental reasons that affected the development of the energy security sector within NATO structural organization. First, the post-Cold War period crystallized the gradual transformation of the Alliance. NATO is continuously transforming, and is adapting to new trends of threats and security. It was obvious that NATO didn't kept the Cold War traits of been a defensive organization, nor NATO became a security organization in a broader context. By such a comprehensive policy, NATO defined a multidimensional and diverse approach towards the threats. In this context, the Alliance aimed in ensuring a reliable supply of petroleum and gas to NATO member states. This reality has begun to dawn on most NATO members, and yet, to date the Alliance formulated the aspiration for the energy security with NATO Wales Declaration in 2014. Significant progress on energy security has expended the collective responsibility of NATO member states. The concept of energy security has evolved over time, covering a range list of issues that include the protection of critical infrastructure, security of energy supply and fair price, and the diversification of energy transit routes.

Second, the growing concern that Russia will continue to use energy to dominate over the European market has brought further energy security into concern. The broader political threats to energy security came to prominence in NATO following the Ukraine-Gazprom gas dispute of early January 2006 (Monaghan, 2008). This event stimulated a higher discussion on "energy security" within the Alliance. The Ukraine-Gazprom gas dispute led the Bush administration to introduce the discussion of energy security to NATO in 2006 (Gallis, 2006). The dispute was presented "in an international context of threatened and actual attacks on major installations and supply routes and concerns about the political reliability of major suppliers" (Monaghan, 2008). In addition, soon after in 2008, the Russo-Georgian War affected the development of energy security within NATO. This event signaled the start of an important but highly continuously process: the expansion of NATO energy security policy. The explicit support for NATO energy security policy emerged; but the highly institutionalized influence towards NATO energy security was profiled by the Russia's annexation of Crimea and support for separatists in Ukraine in 2014. This could be marked as the energy security dilemma - the increase of NATO's effort in energy security when 
the energy interest of the member states is threatened by other actor. All of the three distinct but parallel disputes and conflicts were essentially important to install NATO energy security policy.

Third, NATO has developed various relationships with Ukraine, South Caucasus, Central Asia, North Africa, the Middle East, the Gulf countries, South Korea, Japan, Australia, and New Zealand. Such widening and deepening in the relationship of NATO with non-member states, has increasingly linked NATO to major global energy providers. The security and cooperation with those countries became a prioritized policy of NATO. Proving energy security became a concern of NATO because of the need for an alternative to the Russia's gas. NATO partnership particularly with countries in South Caucasus and Central Asia contribute to the diversification of the European energy market, and provide energy security to NATO states in European Union.

The conjunction of these three elements created a strategic environment for NATO to formulate the energy security policy - both at NATO and international level. The energy security became one of NATO's core policies that covered a range of issues that included partnership with key energy producers, critical energy infrastructure protection etc. - all of these explained why the energy security becomes a relevant topic to NATO security.

\section{Azerbaijani energy security concept}

Azerbaijan pursues a multidimensional foreign policy; balanced foreign policy seeks to establish friendly relations with many different actors, but also aims to avoid any potential conflicts. The country participates in joint efforts in addressing regional and global issues. The most priority issues in Azerbaijani security policy include: regional security, combating terrorism, nonproliferation of weapons of mass destruction and ensuring energy security (National security concepts of the Republic of Azerbaijan, 2007, p. 12).

The regional security and cooperation comes first to the Azerbaijani security concerns, because of myriad of reasons. First, regional cooperation should strengthen the security and stability of the region. Azerbaijan views regional cooperation as an indispensable factor for maintaining peace and stability in the region. In addition, Azerbaijan argues that the absence of foreign military forces in the region would contribute to the regional security. Therefore, the Russian-Armenian bilateral relations that allowed the presence of Russian military troops in Armenia is against the Azerbaijani regional security approach.

Second, the trilateral regional partnership between Azerbaijan, Georgia and Turkey is an important factor for regional stability and energy security. The cooperation between these three actors is crucially important for the transportation of the energy sources. This strategic partnership resulted with successful implementation of infrastructure projects such as BakuSupsa, Baku-Tbilisi-Ceyhan export oil pipelines, South Caucasus gas pipeline (Baku-TbilisiErzurum), and recently approved Trans-Anatolian Natural Gas Pipeline Project (TANAP). All of these projects contributed to the European and global energy security and laid the 
foundations for the new vital and secure energy source for Europe. Among the key tasks of the national security of Azerbaijan are ensuring the security of energy transportation between the Caspian Sea, the Black Sea and the Mediterranean Sea via the Baku-Tbilisi-Ceyhan main export oil pipeline and the South Caucasus gas pipeline (National security concepts of the Republic of Azerbaijan, 2007, p. 19).

Azerbaijan is also interested in cooperating with non-regional actors for addressing the national, regional and global security concerns. The strategic partnership includes cooperation with USA in the framework of the United Nations (UN) and Euro-Atlantic structures, and incorporates: anti-terror coalition, in combating global challenges and threats such as international terrorism, separatism, proliferation of weapons of mass destruction, trans-national organized crime, illegal drug, arms and human trafficking, corruption and on a bilateral basis in political, military, economic, energy security and in promoting democratic reforms (National security concepts of the Republic of Azerbaijan, 2007, p. 14). The relations with the USA helped strengthen Azerbaijan's territorial integrity, secured better economic reforms for its people, promoted regional transportation projects and above all, Washington has highly supported the democratic values and governance in Baku (Tase, 2014).

In addition, Azerbaijan established cooperation with the European Union (EU) on a bilateral and multilateral basis and is interested in deepening integration into European economic space. Since 1992 the EU provided assistance to Azerbaijan throughout the Technical Aid to the Commonwealth of Independent States (TACIS) programme. ${ }^{3}$ The support includes humanitarian assistance, food aid, budgetary support and rehabilitation assistance etc. (Betley, Bird and Napodano, 2000). Under the TACIS indicative program for Azerbaijan, priority is given to the three areas of cooperation: infrastructure, private sector and human resources development (Ministry of Foreign Affairs, Republic of Azerbaijan, n.d). Also, one of the main TACIS strategies in Azerbaijan was the support for economic reforms and the establishment of appropriate legislative, policy and institutional frameworks. More importantly, the restructuring and strengthening of the energy sector in Azerbaijan was one of the key targeted area (Betley, Bird and Napodano, 2000). This also included feasibility studies in the energy sector.

In 1996 Azerbaijan signed Partnership and Cooperation Agreement (PCA) with the EU which entered into force in 1999 (European Union External Action, 2016). The EU sent its special envoy to Azerbaijan in 1998 and Azerbaijan created its permanent representation in EU in 2000 (Ministry of Foreign Affairs, Republic of Azerbaijan, n.d.).The EU-Azerbaijan relations focus to expand economic and political cooperation, in particular with the Baltic, East and South-East European States. For the EU, Azerbaijan is a key partner on Caspian regional energy projects (Paul and Rzayeva, 2011). Also Azerbaijan developed bilateral and multilateral cooperation with states in the Middle East, Central Asia, Far East and South-East Asia.

3 TACIS was designed in 1991to improvement of the financial status of the New Independent States of the Former Soviet Union and Mongolia. 
Importantly, Azerbaijan works together with NATO to eliminate instability, conflicts and threats in European and the Euro-Atlantic area. The integration into the Euro-Atlantic security system is one of the main objectives of the defense policy of Azerbaijan. Also Azerbaijan is determined to share the burden of building a common security system in Europe and in its own region without discrimination on geographic or political grounds (National security concepts of the Republic of Azerbaijan, 2007, p. 9). The country cooperates on a bilateral basis with a number of NATO countries for sharing of experience and exchange of information on the crisis management and prevention of emergency situations. Multilateral cooperation in this area is carried out through NATO mechanisms and Azerbaijan make effective use of these opportunities (National security concepts of the Republic of Azerbaijan, 2007, p. 21).

NATO-Azerbaijan relations in the energy security sphere expanded more by the Wales Summit in 2014 and the Warsaw Summit in 2016.Therefore, NATO security concepts regarding the energy security are applicable to Azerbaijani energy security.

\section{NATO's energy security concept}

NATO has increasingly recognized the concerns about the energy security for the member states. Responding to market-linked and geopolitical challenges, the need for a comprehensive energy security strategy was visible. The Alliance recognized the need to defend its vital strategic interest - securing accessibility to natural resources and diversifying the suppliers; as it was defining at the Riga Summit in 2006:

"As underscored in NATO's Strategic Concept, Alliance security interests can also be affected by the disruption of the flow of vital resources. We support a coordinated, international effort to assess risks to energy infrastructures and to promote energy infrastructure security. With this in mind, we direct the Council in Permanent Session to consult on the most immediate risks in the field of energy security, in order to define those areas where NATO may add value to safeguard the security interests of the Allies and, upon request, assist national and international efforts"(NATO Riga Summit Declaration, 2006).

Two words in the excerpt above are important: disruption and infrastructure. NATO noted that its security interests can be affected by the interruption of the flow of energy resources (Legendre, 2007). This stimulated the further evolution of NATO energy security at the Bucharest Summit in 2008. By the Bucharest Declaration, NATO decided to contribute to energy security by engaging through: information and intelligence fusion and sharing, projecting stability, advancing international and regional cooperation, supporting consequence management, and supporting the protection of critical energy infrastructure. The term, add value, in Bucharest Declaration, was important to avoid duplication of actions of other actors in the international system.

In 2010, the Lisbon Summit further emphasized the energy security policy. The Lisbon Declaration crystallized NATO's commitment to enhanced consolation and cooperation with 
NATO partner states and other international actors by resolving the energy security concerns. Most importantly, in November 2010 NATO adopted a New Strategic Concept at the Lisbon Summit, in which the Alliance argued that NATO would "develop the capacity to contribute to energy security, including protection of critical energy infrastructure and transit areas and lines, cooperation with partners, and consultations among Allies on the basis of strategic assessments and contingency planning" (Lisbon Summit Declaration, 2010, p. 17).

In 2012, the Chicago Summit asserted that "stable and reliable energy supply, diversification of routes, suppliers and energy resources, and the interconnectivity of energy networks, remain of critical importance" (NATO Chicago Summit, 2012).The primary responsibility lied in the diversification of the suppliers to reduce overdependence on a single supplier. More importantly, the Chicago Summit welcomed the offer to establish a NATO-accredited Energy Security Centre of Excellence in Lithuania as a contribution to NATO's efforts in this area. On other hand, in 2014, at the Wales Summit, the Alliance showed the willingness to continue NATO and EU dialogue on energy security. The new form of cooperation in the energy security included the maritime security. This is important because a growing share of energy resources - both oil and natural gas - is produced offshore and transported by sea.

More recently, by the Warsaw Summit Communiqué in 2016, the Alliance set to provide consultation and share information on "energy security issues of particular concern to Allies and the Alliance, with a view to providing a comprehensive picture of the evolving energy landscape, concentrating on areas where NATO can add value". Also NATO asserted to develop capacity to support national authorities in protecting critical energy infrastructure, as well as enhancing their resilience against energy supply disruptions that could affect national and collective defense (Warsaw Summit Communiqué, 2016). Therefore, one of the major threats for NATO member states is the disruption of the energy supply chain by the means of terrorist attacks or conflicts. The supply chain of energy resources includes: range of infrastructural component, drilling, production, storage, transportation and supply. The Alliance could react on a supply disruption.

\section{Critical energy infrastructure and the Western investm ent in Azerbaijan}

Azerbaijan is one of the oldest oil producing countries in the world, but today it is an important oil and gas producer (US Energy Administration, 2016). The major critical energy infrastructures in the South Caucasus are located in Azerbaijan. The Azerbaijani energy infrastructure is of a vital interest to NATO and the European Union because of its geo-strategic position. Traditionally, the country has been an oil-producer, but the importance of the gas supply will mark the future of Azerbaijan, particularly to the EU market. Any threat to the critical energy infrastructure in Azerbaijan would mean less possibility to the diversification of the gas suppliers to EU.

There are few important critical energy infrastructures in Azerbaijan, and all of them are either an important supplier to the regional or international market. The energy infrastructure can be divided into four major categories: oilfield, gas field, existing natural gas and oil pipelines $\bigotimes$, and 
planned natural gas and oil pipelines. The energy security plays an essential role for all of the four major categories, because if the instability is presented in the energy fields and pipelines, there will be uncertainty in the supply and most probably less chance for building new energy corridors. Therefore, proving protection to the existing critical energy infrastructure is important for the future development of the energetic corridors.

One of the core energy infrastructures in Azerbaijan is the Azeri-Chirag-Deepwater Gunashli oilfield (ACG).The ACG started with the oil production in 1997, and it was Azerbaijan's first offshore Production Sharing Agreement (PSA). The British Petroleum in the "BP in Azerbaijan Sustainability Report 2015" says that in 2015, ACG produced an average of 634 thousand barrels per day (more than 231 million barrels or 31.3 million tons in total) from the ACG complex. ACG also delivered around 8.9 million cubic meters per day of ACG associated gas to the State Oil Company of the Republic of Azerbaijan (SOCAR) which equates to 3.2 billion cubic meters in total. Since 1997 to the end of 2015, Baku-Tbilisi-Ceyhan (BTC) has carried a total of about 2.36 billion barrels (315 million tons) of crude oil loaded on more than 3,112 tankers and sent to world markets.

ACG also represented the first major investment by Western multinational companies in any country of the former Soviet Union and became known as The Contract of the Century (British Petroleum Azerbaijan, 2016). Azeri-Chirag-Deepwater Gunashli oilfield was formed by eleven foreign companies from six different nations (UK, USA, Russia, Norway, Turkey and Saudi Arabia). The majority of the ACG is owned by the Western companies. Today the ACG is owned by nine different companies from seven nations.

Table I: Indicates the Co-ventures of ACG (Source: British Petroleum Azerbaijan, 2016). Retrieved from http://www.bp.com/en_az/caspian/operationsprojects/ACG.html. Authors' compilation.

\begin{tabular}{|c|l|l|l|}
\hline No & Name of company & Percentage of ownership & Country \\
\hline $\mathbf{1}$ & BP & $35.7828 \%$ & United Kingdom (UK) \\
\hline $\mathbf{2}$ & SOCAR & $11.6461 \%$ & Azerbaijan \\
\hline $\mathbf{3}$ & Chevron & $11.2729 \%$ & United States \\
\hline $\mathbf{4}$ & INPEX & $10.9644 \%$ & Japan \\
\hline $\mathbf{5}$ & Statoil & $8.5633 \%$ & Norway \\
\hline $\mathbf{6}$ & ExxonMobil & $8.0006 \%$ & United States \\
\hline $\mathbf{7}$ & TPAO & $6.7500 \%$ & Turkey \\
\hline $\mathbf{8}$ & ITOCHU & $4.2986 \%$ & Japan \\
\hline $\mathbf{9}$ & ONGC & $2.7213 \%$ & India \\
\hline
\end{tabular}

The ACG is a complex of six production platforms: Chirag 1, Central Azeri, West Azeri, East Azeri, Deepwater Gunashli, West Chirag; and two process, gas compression, water injection and utilities (PCWU) platforms, equipped with latest technologies. The investment in ACB by 2016 had reached more than $\$ 32$ billion (British Petroleum, 2016). The protection of ACG energy 
infrastructure is important for all seven governments whose companies are operating under the ACG.

Another very important energy infrastructure in Azerbaijan is the Shah Deniz gas field (SD), which is the largest gas field in Azerbaijan. SD was discovered in 1999. The field lies beneath water depths ranging from 50-600 meters. Production began in 2006.The Shah Deniz discovery is Azerbaijan's most important gas field with commercial gas reserves of $1.2 \mathrm{tcm}$, and some of this has been already contracted. In 2015, the output comprises almost $9 \mathrm{bcm} / \mathrm{a}$ of gas contracted for Phase 1 and up to $17 \mathrm{bcm} / \mathrm{a}$ contracted for Phase 2 (Rzayeva, 2015).

According to British Petroleum (BP) in Azerbaijan (2016), SD Phase 2, or Full Field Development (FFD) is a giant project that will add a further 16 billion cubic meters per year (bcma) of gas production to the approximately $9 \mathrm{bcma}$ produced by SD Phase 1.SD Phase 2 will be carried some 3,500 km to provide energy for millions of consumers in Turkey, Greece, Bulgaria, Italy and countries in Europe (Aslanbayli, 2015).

Around $\$ 28$ billion in capital investment will be required to produce the gas and transport it to the Georgia-Turkey border. This will lead to an additional pipeline systems will deliver $6 \mathrm{bcma}$ of gas to Turkey and a further $10 \mathrm{bcma}$ of gas to markets in Europe, in a route known as the Southern Gas Corridor. The EU has identified the Southern Gas Corridor route as a strategic project to get alternative suppliers (European Commission, 2016). SD Phase 2 is one of the largest world gas projects, and it will contribute to the European energy security, which is an essential policy of NATO. Therefore, SD is considered to be additional and alternative natural gas volumes to EU member countries. This represents the very importance of SD, because the EU member states are aiming to reduce the dependency on the Russian natural gas. SD is owned by seven different companies from six countries.

Table 2: Indicates the Co-ventures of SD (Source: British Petroleum Azerbaijan, 2016). Retrieved from http://www.bp.com/en_az/caspian/operationsprojects/Shahdeniz.html. Authors' compilation.

\begin{tabular}{|c|l|l|l|}
\hline No & Name of company & Percentage of ownership & Country \\
\hline $\mathbf{1}$ & BP & $28.8 \%$ & United Kingdom (UK) \\
\hline $\mathbf{2}$ & TPAO & $19 \%$ & Turkey \\
\hline $\mathbf{3}$ & SOCAR & $10 \%$ & Azerbaijan \\
\hline $\mathbf{4}$ & PETRONAS & $15.5 \%$ & Malaysia \\
\hline $\mathbf{5}$ & SGC Upstream & $6.7 \%$ & Azerbaijan \\
\hline $\mathbf{6}$ & LUKoil & $10 \%$ & Russia \\
\hline $\mathbf{7}$ & NIOC & $10 \%$ & Iran \\
\hline
\end{tabular}

Both ACG and SD are connected via offshore and onshore pipeline systems to the Sangachal Terminal, one of the biggest terminals in the world. The Sangachal terminal is a vital link in Azerbaijan's oil and gas industry. It is an oil and gas terminal that receives, processes, stores and 
exports crude oil and gas produced from all currently operated BP assets in the Caspian basin and has room for expansion. The Sangachal Terminal is the first pump station for the Baku Tbilisi Ceyhan (BTC) oil pipeline and South Caucasus gas pipeline (SCP) compressor and other facilities. It has a processing capacity of 1.2 million barrels of oil per day and about 29.5 million standard cubic meters of SD gas, while overall processing and export capacity for gas, including ACG associated gas is about 49.3 million standard cubic meters per day. As part of SD Phase 2, Sangachal terminal undergoes a major expansion. This will allow an additional 16 billion cubic meters of gas per year to be processed (British Petroleum, 2016).

BTC pipeline $(1768 \mathrm{~km})$ carries oil from the Azeri-Chirag-Deepwater Gunashli (ACG) field and condensate from Shah Deniz across Azerbaijan, Georgia and Turkey. BTC is links Sangachal terminal on the shores of the Caspian Sea to Ceyhan marine terminal on the Turkish Mediterranean coast. In addition, crude oil from Turkmenistan and Kazakhstan is transported via the link, but the BTC pipeline currently carries mainly ACG crude oil and Shah Deniz condensate from Azerbaijan. The transportation capacity of the BTC pipeline is 1.2 million barrels per day (British Petroleum, 2016).

The South Caucasus gas pipeline (SCP) was constructed to export Shah Deniz gas from Azerbaijan to Georgia and Turkey. The SCP is also known as Baku-Tbilisi-Erzurum Pipeline (BTE).The pipeline operates since late 2006 and delivers gas from Sangachal Terminal, and it follows the route of BTC crude oil pipeline. During 2015, its daily average throughput was about 18.6 million cubic meters of gas per day (British Petroleum, 2015). While in 2016, its daily average throughput increased to 20 million cubic meters of gas per day (British Petroleum, 2016).

Beside the BTC and SCP existing pipelines, the Trans-Anatolian Natural Gas Pipeline Project (TANAP) aims to bring natural gas produced from Azerbaijan's Shah Deniz 2 gas field, and other areas of the Caspian Sea, primarily to Turkey, but also on to Europe. The TANAP along with BTC and SCP pipelines form the Southern Gas Corridor (TANAP, n.d.). The objective of the TANAP is to diversify Azerbaijan's gas export markets and improve the security of Turkey's and South East Europe's energy supply (World Bank, 2016). The TANAP project will succeed in diversifying the gas market in the European Union. This is an important agenda because many EU members are also NATO member states.

Azeri energy giant State Oil Company of Azerbaijan (SOCAR) holds a 58 percent interest in TANAP, Turkey's BOTAS has a 30 percent share while BP owns a 12 percent stake. The World Bank in December 2016 approved the TANAP project with US \$800 million: \$400 million loan for Turkey and $\$ 400$ million loan for Azerbaijan (World Bank, 2016). The TANAP starts from the Georgia/Turkey border at Türkgözü/Posof/Ardahan where it connects to South Caucasus Pipeline (SCP) and ends at the Turkey/Greece border in Ipsala/Edirne, where it feeds into the Trans Adriatic Pipeline (TAP), and continues the supply to the European countries. The project is planned to be operational in 2018 with an initial capacity to carry 16 billion cubic meters $(\mathrm{bcm})$ or around 565 billion cubic feet (bcf) of Azeri gas (Tekfen Construction, 2016).This would 
be about half the capacity of the originally proposed Nabucco project ${ }^{4}$ (Ratner, Belkin, Nichol, Woehrel, 2013).

However, Azerbaijan with its existing energy infrastructure and with the new TANAP approved project play a significant role in the energy security of the Euro-Athletic Community. Any potential threat to any component of the Azerbaijani energy supply would affect the energy security of the Euro-Athletic Community. Therefore, protection of Azerbaijani critical energy infrastructure is the interest of multiple actors: Azerbaijan itself, NATO, EU, and the multinational companies operating in Azerbaijan. The protection of the Azerbaijan and the Caspian region brought further attention as a result of Ukraine Crisis in 2014.

\section{NATO and security of critical energy infrastructure in Azerbaijan}

Energy security has become a major concern of European Union and NATO in the last decade. The majority of the Euro-Atlantic states are far away from energy supplier countries, which brings them difficulty to diversify their energy resources supply. They are more dependent on short-distance suppliers (e.g. Russia and Norway). Therefore, the European NATO member states depend on series of external developments that affect their energy security, some of them are: political use of energy resources by the supplier countries, growing threat of terrorist attacks on energy infrastructure, rise in the demand of energy resources by developing countries etc.

Growing importance of energy supply and strong dependence of NATO's European member states on third party suppliers, as well as the security threats in the neighborhood require the Alliance to set up a concrete policy framework for energy security (Gurbanov, 2015). The new energy security framework aims in diversifying the current energy suppliers. The EU receives supplies of energy resources from variety of countries worldwide - but the most remarkable amount are from Russia and Norway. In 2012, the Norway's gas accounted for $31 \%$ of all the EU's natural gas, and $11 \%$ of all the EU's crude oil import. On the other hand, in 2013, the Russia's gas accounted for 39\% of EU's natural gas imports (European Commission, n.d.). High dependence on the Norwegian gas does not present a threat to the EU and the European NATO member states, because Norway is a NATO member since 1949. In regarding to this, the energy security has become a significant factor driving deepening international engagement with the Caucasus region and there is a need to ensure security and stability of export routes (German, 2008).

4 The Nabucco pipeline project represented an opportunity for the European Union (EU) to diversify the gas supply and to reduce its reliance on Russia. This pipeline would transport the gas reserves from the Caspian Sea to Europe. The Nabucco pipeline was projected to carry 31 billion cubic meters (bcm) or around 1130 billion cubic feet (bcf) of gas. Azerbaijan was ready to deliver approximately $10 \mathrm{bcm}$ while the rest would be shared by other Caspian countries. The Nabucco project could be consider as a hand that would give "a sense of supply security" to the EU, but also it would be a strong financial project of Azerbaijan and nearby countries. However, the failure of the Nabucco projected awakened the Europeans in the sense of serious geopolitical agenda and the awareness of the need for the natural recourses supply diversification. 
Table 3: Main origin of primary energy imports, EU-28, 2004-14 (\% of extra EU-28 imports). Retrieved from http://ec.europa.eu/eurostat/statistics-explained/index.php/File:Main_origin_of_primary_energy_ imports,_EU-28,_2004\%E2\%80\%9314_(\%25_of_extra_EU-28_imports)_YBI6.png. Authors' compilation.

\begin{tabular}{|l|c|c|c|c|c|c|c|c|c|c|c|}
\hline Country & $\mathbf{2 0 0 4}$ & $\mathbf{2 0 0 5}$ & $\mathbf{2 0 0 6}$ & $\mathbf{2 0 0 7}$ & $\mathbf{2 0 0 8}$ & $\mathbf{2 0 0 9}$ & $\mathbf{2 0 1 0}$ & $\mathbf{2 0 1 1}$ & $\mathbf{2 0 1 2}$ & $\mathbf{2 0 1 3}$ & $\mathbf{2 0 1 4}$ \\
\hline Russia & 32,5 & 32,9 & 33,8 & 33,7 & 31,8 & 33,6 & 34,7 & 34,8 & 33,7 & 33,7 & 30,4 \\
\hline Norway & 18,7 & 16,8 & 15,4 & 15,0 & 15,0 & 15,1 & 13,7 & 12,5 & 11,2 & 11,8 & 13,1 \\
\hline Nigeria & 2,6 & 3,2 & 3,6 & 2,7 & 4,0 & 4,5 & 4,1 & 6,1 & 8,2 & 8,1 & 9,1 \\
\hline Saudi Arabia & 11,3 & 10,5 & 9,0 & 7,2 & 6,8 & 5,7 & 5,9 & 8,0 & 8,8 & 8,7 & 8,9 \\
\hline Kazakhstan & 3,3 & 4,4 & 4,6 & 4,6 & 4,8 & 5,3 & 5,5 & 5,7 & 5,1 & 5,7 & 6,4 \\
\hline Iraq & 2,2 & 2,1 & 2,9 & 3,4 & 3,3 & 3,8 & 3,2 & 3,6 & 4,1 & 3,6 & 4,6 \\
\hline Azerbaijan & 0,9 & 1,3 & 2,2 & 3,0 & 3,2 & 4,0 & 4,4 & 4,9 & 3,9 & 4,8 & 4,4 \\
\hline Algeria & 3,3 & 3,5 & 2,5 & 1,9 & 2,5 & 1,6 & 1,2 & 2,6 & 2,9 & 3,9 & 4,2 \\
\hline Angola & 0,6 & 1,2 & 0,7 & 2,0 & 2,6 & 2,7 & 1,6 & 2,1 & 2,0 & 2,9 & 3,3 \\
\hline Others & 24,5 & 24,0 & 25,2 & 26,6 & 26,0 & 23,8 & 25,6 & 19,8 & 20,1 & 16,7 & 15,4 \\
\hline
\end{tabular}

Azerbaijan as a developer of rich hydrocarbon resources plays an important role in diversification of oil and gas supplies in the global market; and the security of Azerbaijan is essential for the Alliances. One should not forget the important geopolitical location of Azerbaijan and its regional role. A number of successful energy projects such as Baku-Tbilisi-Ceyhan export oil pipelines and the South Caucasus gas pipeline (Baku-Tbilisi-Erzurum) have increased the importance of the Black Sea and Caspian Sea regions and contributed to European and global energy security(Larsson, 2008). Additionally, the security of Azerbaijan is important to NATO because of many large financial investments made by giant companies from the allied countries in Azerbaijani energy sector (Mammadov, 2010). Therefore, it is not surprising that from 1994 and outward NATO-Azerbaijan relations have tightened.

With its current energy infrastructure and growing energy potential, Azerbaijan is playing an essential role in energy supply to the Euro-Atlantic region. Azerbaijan's proved crude oil reserves were estimated at 7 billion barrels at the end of 2015, according to the Oil \& Gas Journal (OGJ). In 2015, Azerbaijan produced about 850,000 barrels per day (b/d) of petroleum and other liquids and consumed about 100,000 b/d (US Energy Administration, 2016). The most of the produced crude oil and gas pass transported via Georgia and Turkey, and then to the international market. Any threat in the transportation, either the pipelines or the oil platform) could disrupt the supplying chain.

However, the protection of critical energy infrastructure inside a country is primarily a national security concept. Each country faces its specific threats and must make its own decisions on neutralization of such threats as a part of national security strategy (Aslanbayli, 2015). Nevertheless, nowadays the energy supply map is much internationalized, and the protection of critical energy infrastructure goes beyond the national level. On the other side, dealing with the protection of the critical energy infrastructure is even more important when it serves to millions 
of people. But more importantly, in NATO-Azerbaijani case, it plays an essential agenda in NATO energy security, because the Azerbaijani energy resources can be an alternative to the Russian gas.

The transformation of NATO's energy security policy offered more guarantees and opportunities for Azerbaijan's protection of critical energy infrastructure in a broader context. Starting from Riga Summit Declaration in 2008 to the Warsaw Summit Communiqué in 2016, NATO developed different means to support the member and partner states in the protection of critical energy infrastructure. NATO agenda for the support of partner states, such as Azerbaijan, includes: information and intelligence fusion and sharing, projecting regional stability, advancing regional and international cooperation, supporting consequence management, training and workshops with NATO-accredited Energy Security Centre of Excellence (both landscape and maritime security), and supporting the protection of critical infrastructure.

The importance of the energy security can be explained as guarantee that the energy supplies flow smoothly from Azerbaijan to the final destination - depends on the protection of critical energy infrastructure. Utmost attention of the protection of critical energy infrastructure is the protection of the existing gas grid and oil pipelines or the new projected networks (e.g. transCaspian pipeline, and recently approved TANAP pipeline). William Lahue, NATO Liaison Officer in the South Caucasus, in 2015, declared that "what NATO will be able to do is to pull partners looking for protection of critical energy infrastructure and in that way; we [NATO] can help facilitate trainings, education for the national organizations working in this sphere for protection of infrastructure" (Azernews, 2015).

On the other hand, we have to keep in mind that NATO is not an energy institution, and is not involved in creation and building of energy corridors and pipelines; but rather provides security to critical energy infrastructure. The implementation of the projects is in the hands of the countries. It means that the Azerbaijani pipelines projects which aim to diversify the energy market in EU are primary responsibility of Azerbaijan, the EU and countries taking a part in such projects. However, NATO is more and more interested in the energy security of the EU. During the Wales Summit in 2014, the Alliance declared that stable and reliable energy supply, the diversification of routes (the pipelines), suppliers and energy resources remain of critical importance for NATO. In this regards, energy projects that will diversify the EU market will bring also energy security to NATO.

NATO is in a position to complement the EU's energy security initiatives, because of the partnerships it has cultivated in the Caucasus and Central Asia. In addition, most EU member states are also members of NATO, and energy security may emerge as an issue handled in a joint initiative by these two organizations. The protection of the Azerbaijani critical energy infrastructure is vital to both EU and NATO, but Azerbaijan must further integrate towards NATO. NATO Secretary General Anders Fogh Rasmussen said during a joint press point with Azerbaijani President Ilham Aliyev in Brussels, in 2014, that Azerbaijan is a country of pivotal 
importance for Europe's energy security and to peace and stability in the Caucasus (European Dialogue, 2014).

The tightened NATO-Azerbaijan relationship would provide Azerbaijan additional guarantees that are vital for the protection of the country's critical energy infrastructure. Any further NATOAzerbaijan relationship would have an impact on the energy security of NATO member states, and in particular those members of the European Union, as they seek to diversify their oil and gas supplies. In regards, NATO support for the Azerbaijani energy security includes: exchange information and best practices for energy infrastructure security, organizations of conferences and scientific workshops that analyze new threats to infrastructure (e.g. cyber-attacks), discuss solutions for resilience, consultation on regional energy security vulnerabilities in NATO committees, and energy training and education activities.

\section{Conclusion}

In the early years of independence, Azerbaijan selected the policy of diversification of transport routes to export its energy resources to the international markets. This has led to extraordinary amount of foreign investment inflow in the energy market sector. One of the key tasks of the national security of Azerbaijan is ensuring the security of energy corridors and the transportation of the energy resources.

The energy supply map is much internationalized, and the protection of critical energy infrastructure goes beyond the national level. This requires from Azerbaijan to seek for regional cooperation and stable regional security, which could be assisted by NATO. It is unavoidable to speak about the Azerbaijan's energy supply transit but not to mention Georgia. There cannot be a systematic division between Azerbaijan and Georgia because Georgia is the Azerbaijan's main transit and strategic ally in the South Caucasus. Georgia is the preferable transit country of the Azerbaijani natural resources to Europe and Turkey. Therefore, the destabilization in Georgia, either political or territorial (Russia's invasion) could have negative effects on Azerbaijan's economy. This study has demonstrated that transit countries have not developed any specific concept of energy security and that the instability of them affects the producers of energy resources. A mutual understanding of the issues of security of supply among the energy exporters and the transit countries is important.

Additionally, Russia is not pleased to see the Georgia's NATO membership (partner) aspiration. There is a higher chance that Russia would try to indirectly influence Azerbaijan through the conflict with Georgia and its support for Armenia in the open Nagorno-Karabakh dispute, than directly to be conflicted with Azerbaijan. Also, Russia's economy is highly dependent on exports of crude oil, petroleum products, and natural gas accounting for about a half of Russia's federal budget (Trading Economics, 2017). Russia's need to protect its dominance in the natural resources market is higher than the interest of the Western countries to diversify the suppliers. 
Stephen Walt's "balance of threat" theory postulate that states form alliances (or join the existed one) to prevent stronger powers from dominating them and to protect themselves from states or coalitions whose superiority threaten their national integrity. Unlike Georgia and Ukraine, Azerbaijan appears a bastion of stability. Among its advantages is the strong relation with NATO and the national consensus for such cooperation. Also, the strong link with Turkey is of a strategic importance for any planned pipelines project. However, by looking on the examples of Georgia and Ukraine, and on the Russia's influence on the Nagorno-Karabakh dispute, it would be advisable for Azerbaijan to strengthen relations with NATO and Turkey to avoid Georgia's or Ukraine's scenarios. Additionally, the "rational-choice institutionalism" theory argues that states use institutions to maximize their utility. In other words, this theoretical assumption pushes the argument that states create or join institutions to maximize their benefits which are often conceptualized through strategic cooperation (Shepsle, 2008). The decision to join an organization (or institution) is resulted out of rational and purposive interactions with other states to solve a particular issue. It could be elaborated that NATO as a rational-purposive organization could assist Azerbaijan to keep critical energy infrastructure secure.

On the other hand, the study showed that the Alliance is evolving into a comprehensive security provider that considers a range of threats to its member and partner states. These threats include the energy security which is widely accepted as a threat by both the international and national security policy. The evolving NATO energy security from NATO Riga Summit in 2008 to Warsaw Summit Communiqué in 2016 offered more opportunities for the protection of critical energy infrastructure in Azerbaijan, and incorporates: exchange information and best practices for energy infrastructure security, organizations of conferences and scientific workshops that analyze new threats to infrastructure (e.g. cyber-attacks), discuss solutions for resilience, consultation on regional energy security vulnerabilities in NATO committees, and energy training and education activities. Nevertheless, there has to be a clear strategy how and under which circumstances NATO would take a role in the protection of the Azerbaijani critical energy infrastructure. The Russia-Georgia War in 2008 showed that there is not clear NATO security strategy for the Caucasus region. The same applies to Russia-Ukraine War in 2014 when NATO again showed lack of strategy.

The security of Azerbaijan and its critical energy infrastructure is an important agenda for NATO because the Azerbaijani alternative energy corridors would help seal Europe off from the Russian gas dominance. The stronger Azerbaijani energy contribution to the European market is; the greater NATO's involvement in Azerbaijan's energy security will be. However, as already said, clear strategy by the Alliance is strongly needed with an efficient application through appropriate policy instruments. Azerbaijan still has a long way to go before it can join NATO, but it seems that the integration process works the best for Azerbaijan in the South Caucasus. The establishment of strong Azerbaijani relations with the Western countries, and the reaching the support of NATO in the protection of critical energy infrastructure is important for Azerbaijan because its "economy is based on oil and gas extraction which account for 95 percent of exports and 75 percent of government revenues" (Trading Economics, 2017). With new pipelines project and 
the increment of gas supply to Europe and Turkey, Azerbaijan will improve its economy. The energy relations between Europe (West) and Azerbaijan could be consider as a win-win situation. Azerbaijan is reaching the biggest world's single market, while the Europe is filling up the gap of natural resources suppliers. 


\section{References}

Aslanbayli, B. (2015). NATO's Possible Role in the Protection of Critical Energy Infrastructure in Azerbaijan. Caucasus International,3(4), pp. 133-143.

Azernews. (2015, July 12). NATO: Azerbaijan becoming important component of global energy security. Retrieved from http://www.azernews.az/nation/85630.html.

Betley M., Bird, A. \& Napodano, M. (2000). Evaluation of EC Tacis Country Strategy: Azerbaijan 1996-1999. Investment Development Consultancy, France \& Development Strategies, Italy. Retrieved from ec.europa.eu/europeaid/how/evaluation/evaluation_reports/reports/tacis/951538_en.pdf.

British Petroleum. (2015). BP in Azerbaijan Sustainability Report 2015. Retrieved from http://www.bp.com/ content/dam/bp/pdf/sustainability/country-reports/bp-sustainability-report-2015-azerbaijan.pdf.

British Petroleum. (2016). BP Statistical Review of World Energy June 2016. Retrieved from https://www. bp.com/content/dam/bp/pdf/energy-economics/statistical-review-2016/bp-statistical-review-ofworld-energy-2016-full-report.pdf.

British Petroleum. (2016). Baku-Tbilisi-Ceyhan pipeline. Retrieved from http://www.bp.com/en_az/caspian/ operationsprojects/pipelines/BTC.html.

British Petroleum. (2016). South Caucasus pipeline. Retrieved from http://www.bp.com/en_az/caspian/ operationsprojects/pipelines/SCP.html.

British Petroleum. (2016). Azeri-Chirag-Deepwater Gunashli. Retrieved from http://www.bp.com/en_az/ caspian/operationsprojects/ACG.html.

British Petroleum. (2016). Shah Deniz Stage 2. Retrieved from www.bp.com/en_az/caspian/ operationsprojects/Shahdeniz/SDstage2.html

British Petroleum. (2016). Shah Deniz Stage 1. Retrieved from http://www.bp.com/en_az/caspian/ operationsprojects/Shahdeniz/SDstage1.html

Choucric, N. (1977). International Politics of Energy Interdependence, Lexington Books.

European Commission. (n.d.). Supplier countries, Energy. Retrieved from https://ec.europa.eu/energy/en/ topics/imports-and-secure-supplies/supplier-countries.

European Commission. (n.d.). Supplier countries Retrieved from https://ec.europa.eu/energy/en/topics/ imports-and-secure-supplies/supplier-countries.

European Commission. (2016). EU-Azerbaijan Joint Declaration on the Southern Gas Corridor. Retrieved from https://ec.europa.eu/energy/sites/ener/files/Joint_Declaration_Baku_2016.pdf.

European Dialogue. (2014). NATO: Azerbaijan is a country of pivotal importance for Europe's energy security. Retrieved from https://www.eurodialogue.eu/\%20NATO-Azerbaijan-is-a-country-of-pivotalimportance-for-Europe-energy-security.

European Union External Action. (September 9, 2016). EU-Azerbaijan Partnership and Cooperation Agreement (1999). Retrieved from https://eeas.europa.eu/sites/eeas/files/eu-az_pca_full_text_0.pdf.

Eurostat, Statistics Explained. File:Main origin of primary energy imports, EU-28, 2004-14 (\% of extra EU28 imports) YB16.png. Retrieved from http://ec.europa.eu/eurostat/statistics-explained/index.php/ File:Main_origin_of_primary_energy_imports,_EU-28,_2004\%E2\%80\%9314_(\%25_of_extra_ EU-28_imports)_YB16.png.

Gallis, P. (2006). NATO and Energy Security. Congressional Research Service (CRS) Report for Congress.

Galiyev, P. (2014). The Impact of the Ukrainian Crisis on the Foreign Policy of Azerbaijan Republic. Retrieved from http://4liberty.eu/impact-ukrainian-crisis-foreign-policy-azerbaijan-republic/.

German, T. C. (2008). Corridor of Power: The Caucasus and Energy Security. Caucasian Review of International Affairs, 2(2), pp. 64-73. 
Gurbanov, I. (2015). Importance of NATO's Engagement in Critical Energy Infrastructure Protection in the South Caucasus. Caucasus International, 5(3), pp. 89-100.

Ismayilov, K. \& Zasztowt, K. (2015). Azerbaijan's Risky Game between Russia and the West. The Polish Institute on International Affairs. Policy Paper, 32(134), pp. 1-6.

Koremenos, B. \& Lipson, C. (2001).The Rational Design of International Institutions. International Organization 55(4), pp. 761-799.

Labandeira, X. \& Manzano, B. (2012). Some Economic Aspects of Energy Security. Economic for Energy. Retrieved from http://eforenergy.org/en/.

Larsson, R. L. (2008). Security implications of the North Stream Project. For the European Parliament. Retrieved from www.europarl.europa.eu/RegData/etudes/note/join/2008/388931/EXPO-AFET_ NT(2008)388931_EN.pdf.

Legendre, T. (2007). The North Atlantic Treaty Organization's Future Role in Energy Security. The Whitehead Journal of Diplomacy and International Relations, 8(2), pp. 1-8.

MacDougall, J. C. (2009). Post-Soviet Strategic Alignment: The Weight of History in the South Caucasus. A Dissertation submitted to the Faculty of the Graduate School of Arts and Sciences of Georgetown University in partial fulfillment of the requirements for the degree of Doctor of Philosophy in Government. Retrieved from https://repository.library.georgetown.edu/bitstream/ handle/10822/553091/macDougallJames.pdf.

Mammadov, N. (2010). About the main directions in the Foreign Policy of Azerbaijan. Azerbaijan Focus, 2(2), pp. 17-51.

Minasyan, S. (2013). Russian-Armenian Relations: Affection or Pragmatism?, Elliott School of International Relations, George Washington University, PONARS Eurasia Policy Memo No. 269, pp. 1-5.

Ministry of Foreign Affairs of the Republic of Armenia. (2016). Bilateral Relations - Russia. Retrieved from www.mfa.am/en/country-by-country/ru/.

Ministry of Foreign Affairs, Republic of Azerbaijan. (n.d.). Azerbaijan-European Union. Retrieved from www.mfa.gov.az/en/content/555.

Monaghan, A. (2008). Energy Security: NATO's Limited, Complementary Role. Research Division - NATO Defense College, Rome - No. 36.Retrieved from https://www.files.ethz.ch/isn/56022/rp_36en.pdf

NATO. (2016). Relations with Russia. Retrieved from http://www.nato.int/cps/en/natolive/topics_50090. htm.

NATO Review. (2007). Debate: Should NATO play a major role in energy security? Retrieved from www.nato. $\mathrm{int/docu/review/2007/issue1/english/debate.html.}$

NATO (2006). Riga Summit Declaration (Issued by the Heads of State and Government participating in the meeting of the North Atlantic Council in Riga on 29 November 2006).Retrieved from www.nato.int/ docu/pr/2006/p06-150e.htm.

NATO (2008). Bucharest Summit Declaration (Issued by the Heads of State and Government participating in the meeting of the North Atlantic Council in Bucharest on 3 April 2008). Retrieved from www.nato. int/cps/en/natohq/official_texts_8443.htm.

NATO (2010). Lisbon Summit Declaration (Issued by the Heads of State and Government participating in the meeting of the North Atlantic Council in Lisbon). Retrieved from www.nato.int/cps/en/natohq/ official_texts_68828.htm.

NATO (2012). Chicago Summit Declaration (Issued by the Heads of State and Government participating in the meeting of the North Atlantic Council in Chicago on 20 May 2012). Retrieved from www.nato. int/cps/en/natohq/official_texts_87593.htm?selectedLocale=en. 
NATO (2014). Wales Summit Declaration (Issued by the Heads of State and Government participating in the meeting of the North Atlantic Council in Wales). Retrieved from www.nato.int/cps/cn/natohq/ official_texts_112964.htm.

NATO (2016). Warsaw Summit Communiqué (Issued by the Heads of State and Government participating in the meeting of the North Atlantic Council in Warsaw 8-9 July 2016). Retrieved from www.nato. int/cps/en/natohq/official_texts_133169.htm.

National security concepts of the Republic of Azerbaijan (2007). Retrieved from https://www.files.ethz.ch/ isn/154917/Azerbaijan2007.pdf

Paul, A. and Rzayeva, G. (2011). Azerbaijan - The key to EU energy security, European Policy Center. Retrieved from http://www.epc.eu/documents/uploads/pub_1357_azerbaijan_-_the_key_to_eu_ energy_security.pdf

Ratner, M., Belkin, P., Nichol, J., Woehrel, S. (2013). Europe's Energy Security: Options and Challenges to Natural Gas Supply Diversification. CRS Report for Congress. Retrieved from https://fas.org/sgp/ crs/row/R42405.pdf

Rzayeva, G. (2015). The Outlook for Azerbaijani Gas Supplies to Europe: Challenges and Perspectives. United Kingdom: Oxford University.

Shepsle, A. S. (2008). Rational Choice Institutionalism. In The Oxford Handbook of Political Institutions (pp. 23-39). New York: Oxford University Press.

Shiriyev, Z. (2015). NATO's South Caucasus paradigm: beyond 2014. European Policy Center. Retrieved from http://www.epc.eu/documents/uploads/pub_5598_article_-_zaur_shiriyev.pdf

Stefan, G., Marilena M., Tabriz, G., \& Costel, S. (2013). Points of the states involved in energy projects in South Caucasus. Constanta Maritime University's Annals, 13(8), pp. 289-297.

Süleymanov, E, Aras, O. N., Huseynov, R. (2013). The Importance of Azerbaijan's Energy Revenues in its Exports Volume and the Effects on the National Economy. International Journal of Business and Social Science, 4(6), pp. 79-88.

Tase, P. (2014, April 10). Azerbaijan's strategic relations with the United States. Foreign Policy News. Retrieved from http://foreignpolicynews.org/2014/04/10/azerbaijans-strategic-relations-united-states/

TANAP (n.d.). Trans Anatolian Natural Gas Pipeline Project. Retrieved fromhttp://www.tanap.com/tanapproject/why-tanap/.

Tekfen Construction. (2016). Turkey - TANAP Trans Anatolian Natural Gas Pipeline Project-LOT 3. Retrieved from www.tekfeninsaat.com.tr/pipeline_project_detail.asp?id=25.

Tekfen Construction. (2016). Turkey-TANAP Trans Anatolian Natural Gas Pipeline Project-Compressor and Mattering Stations. Retrieved from www.tekfeninsaat.com.tr/pipeline_project_detail.asp?id=26.

Trading Economics (2017). Russia Exports (1994-2017). Retrieved from www.tradingeconomics.com/ russia/exports.

Trading Economics. (2017). Azerbaijan GDP Annual Growth Rate (2001-2017). Retrieved from www. tradingeconomics.com/azerbaijan/gdp-growth-annual.

US Energy Information Administration. (2016). Country Analysis Brief: Azerbaijan. Retrieved fromhttp:// www.marcon.com/library/country_briefs/Azerbaijan/azerbaijan.pdf

Wallander, C. A. (2000). Institutional Assets and Adaptability: NATO After the Cold War. International Organization 54(4), pp. 705-735.

Walt, S. M (1990). The Origins of Alliance. United States: Cornell University Press. 
World Bank (2016). Trans-Anatolian Natural Gas Pipeline Project (TANAP). Retrieved from http://www. worldbank.org/en/news/loans-credits/2016/12/20/trans-anatolian-natural-gas-pipeline-projecttanap.

World Bank (n.d.). Trans-Anatolian Natural Gas Pipeline Project. Retrieved from http://projects.worldbank. org/P157416?lang=en.

Yildirim, Z. (2012). U.S. Foreign Policy towards Azerbaijan: From "Alliance" to "Strategic Partnership". Alternatives Turkish Journal of International Relations, 11(4), pp. 1-15. 